\title{
AN ISLAND EXPERIENCE
}

\section{OPSOMMING}

Op 'n besoek na St Helena het die skrywer besiuit om meer uit te vind oor verpleegdienste op die eiland.

Die kinderhuis, fasiliteite vir gestremde kinders, geriatriese sorg, distrikverpleging. hospitaalverpleging en verpleegonderwys is ondersoek. Die moderne fasiliteite waaraan ons gewoond is ontbreek heeltemal, so byvoorbeeld moet die distrikverpleegkundige voetslaan om haar besoeke af te lê, en net twee studente kan elke drie jaar vir opleiding na Engeland gestuur word. Die skrywer kom tot die slotsom dat, as al die probleme waarmee die verpleegkundiges op St Helena te kampe het opgeweeg word, ons onsself as bevoorreg kan ag.

\section{NURSING ELSEWHERE}

As you go about your work in your corner of the nursing world, do you ever stop to wonder whether or not nurses in other parts of the world work and study as you do? This aspect of nursing has always been of interest to the author so, while on the Island of St Helena, she decided to see just how nursing there differed from nursing in South Africa.

\section{HISTORICAL BACKGROUND}

Before starting out on her study tour the author went to the public library and the Government archives and read up the medical history of the island which, although very scanty, was extremely interesting. She also read Dr Ian Shine's book, Serendipity in St Helena. Dr Shine had worked on the island for about three years and was especially interested in the genetic disorders on this small island. His book included not only a good description of the genetic disorders found among the islanders, but also a very good background of the history, culture and geography of this little colony with its limited population.

The inhabitants of the island, or saints as they call themselves, are a race originating from the intermingling of Europeans (mainly British) and slaves brought from China and

\section{Nursing in St Helena}

\section{MARGARET A DOYLE}

Africa. Their culture, although very Western in nature, is still tinged with the mystic - they still believe in witchcraft and the evil-eye.

In his book Dr Shine gives some of the local medical terms for certain disorders. They are amusing and extremely apt. Benny scissors had familial genu valgum and clockeyes suffered from congenital nystagmus. Perhaps the most strange was the name boom bang. This was the name given to an albino. His eyes reminded the children of the eyes of a white rabbit and they started off by singing the nursery rhyme: Run, rabbit, run. Father's got a gun, whenever they saw him. This was later shortened to boom bang.

In some instances Dr Shine discovered that the conventional method of asking his patients questions to try and diagnose their problem just would not get him the desired information. For example, the usual question do you get breathless on exertion or perhaps do you ever get a pain across the chest got him some weird answers from his cardiac patients. His safest bet was asking: how often do you stop while climbing the ladder? For those who do not know the island the ladder, or Jacob's Ladder, is 699 steps which are all 11" in height, and which lead straight up from Jamestown to the next level of the island. It took the author 27 long minutes to climb the ladder and, if she had never had a cardiac disorder before the climb, she certainly seemed to have acquired one by the time she eventually dragged herself over the 699th step!

\section{HEALTH SERVICES}

\section{The Children's Home}

Of special interest was the children's home because the author had been a sister at the Ugie Children's Home for three and a half years. The only real difference was that at Ugie there are about 200 children who need love and understanding. On the island, although they have at times had up to 22 children, there are now only 13 children needing the same love and understanding.

Even on this virtually unspoiled corner of the world there are children suffering from the effects of child abuse and broken homes. The home was spotlessly clean and there was the clinical order in the dormitories that is to be found in any institution of this kind. The home is situated at Longwood which is in the country near the house where Napoleon spent his unhappy years of exile. The children happily playing in the grounds did not appear to mind their exile from normal homelife, even though the superintendent assured the author that: $1 \mathrm{am}$ pretty strict Mam, and we have a schedule that the kids must stick to.

\section{Handicapped children}

Unfortunately there are no fascilities for the retarded or handicapped child such as those found in our country. There is no institution or organisation that can offer these children the privilege of learning to use the faculties that they do possess. There are not even wheelchairs to help those who are crippled towards a degree of mobility. There are, however, five schools that offer play-groups for handicapped children twice or three times a week. The transport of the Department of Education collects the children and the Department provides play-group teachers. A start is thus being made in the right direction. 
If one can ever call a handicapped child lucky, then surely those in countries like South Africa where so much is offered in the way of rehabilitation, are lucky!

\section{Geriatric care}

The old people's home was the next place visited. The home was spotless and there was not even a vapour of the presence of incontinence. There was however absolutely nothing available to make the task of the young helpers easier. There was no commode-chair to facilitate going to the toilet nor any useful bathroom apparatus to assist the elderly with getting in and out of the bath - in fact none of the aids that nursing staff in South Africa find necessary for the successful running of the homes for senior citizens.

\section{District nursing}

The author is at present doing district work and remembers with shame all the grumbles about the size of the area to be covered, and the heat and the flies in the wellequipped Kombi. Now she will remember a day spent in the district with another Margaret on that little island in the Atlantic.

Luckily they were given a lift to the first port of call, the school. There the nurse had to do the monthly check for pediculi and scabies, and also give health education.

One advantage here was that the district nurse did not have to contend with a language that she could not understand - no Xhosa or Zulu spoken and no need for an interpreter to try and sort out the communication. But, for a visitor like the author, here was an English needing a pretty agile ear. Who would recognise these few examples for what they are: An ulster? An abster? Roses? Pains in the brains? As we know them they are in order: an ulcer, and abscess, testicles and a headache!

The second call was a house some fifteen minutes walk away. Here a lady needed dressing on her varicose ulsters. After this Margaret and the author wandered along shady paths, slid down inclines and trudged up hills until all the other folk on Margaret's list for the day had been visited. The author very gaily offered to carry the little black bag, but by the end of the day it seemed to have become unbelievably heavy. Here on the island where the terrain is either up or down, there isn't even the joy of cycling along to visit your patients. Two feet are the district girl's only mode of transport.

\section{Hospital nursing and nursing education}

The last place visited was the hospital in Jamestown where some hours were spent talking to Miss Kershaw, the Chief Nursing Officer, about the staffing of the hospital, mental institution and the district. She also explained the education offered to those nurses carrying out the work in the various areas of nursing.

The hospital can accommodate fifty patients but, on an average, the daily total is about twenty. There are twenty-one nurses working at the hospital and, as Miss Kershaw remarked, On paper this looks good, doesn't it? Only three of these nurses are registered nurses and they are all from Britain. There are two staff nurses who had a year's basic training in 1978 . Then there is a staff nurse who has completed the British enrolled nurse training which is almost the same as the training for the nursing assistant in South Africa.

Up until now education has been mainly empirical with the older nurses, some of whom have been at the hospital for over twenty years, passing on their knowledge to the new nurses. The girls recruited for nursing are expected to have three O'-levels, which is on a par with the South African standard eight. Any girls hoping to be chosen to be sent to Britain for training as registered nurses, need five O'-levels. The finances of the country are such, that only two girls can be sent for training every three years.

Miss Kershaw came to the island solely as a nurse educator and has already started a system of training which embraces the theory necessary for really successful functioning.
Even the older nurses, who are excellent nurses, are keen to learn about the composition and functioning of the bodies they are helping to nurse through illness. Under the new system, the girls taken in at the beginning of each year will have an initial block of four weeks followed by one study day every alternate week for three years. Candidates for registered nurse training will be chosen from among these girls.

Unlike in South Africa, preventive nursing plays a very small part. This is something Miss Kershaw is especially keen on introducing into the educational programme.

The district corps consists of three nurses who have had three years of hospital experience and four nurses who have had twelve weeks hospital training. Under the new system, a girl wanting to do district nursing will have to spend three years doing nine-month stretches alternately at the hospital and in the district before she is considered to be a trained district nurse.

The mental hospital is staffed by nurses who can really only give custodial care. A psychiatric nurse is a real need on the island, not only for those in the mental hospital but also to help those folk tucked away out of sight and not helped because of a lack of insight into their problems and general psychiatric knowledge.

In the near future a registered district nurse will be sent out from Britain to assist and train the nurses coping with the district work and it is Miss Kershaw's hope that a fully qualified psychiatric nurse will soon follow.

\section{Conclusion}

We are all inclined to moan and groan about issues like too little pay, too much theory, hours that are too long or inconvenient, and a host of other little pinpricks. When the author, however, reviewed the odds against the girls who are nursing on St Helena, she realised just how privileged those girls in South Africa, who take up nursing as a profession, are.

\section{BIBLIOGRAPHY}

Shine, I. (1960) Serendipity in St Helena. 